\begin{tabular}{c}
\hline $\begin{array}{c}\text { Brazilian Journal } \\
\text { of Chemical } \\
\text { Engineering }\end{array}$ \\
\hline
\end{tabular}

\title{
ATTACHED BIOMASS GROWTH AND SUBSTRATE UTILIZATION RATE IN A MOVING BED BIOFILM REACTOR
}

\author{
J. J. Marques ${ }^{1 *}$, R. R. Souza ${ }^{1}$, C. S. Souza ${ }^{1}$ and I. C. C. Rocha ${ }^{1}$ \\ ${ }^{1}$ Universidade Federal de Sergipe, Phone:+(55) (79) 2105-6687, Fax: +(55) (79) 2105-6679, \\ Av. Marechal Rondon s/n, Rosa Elze São Cristóvão - SE, Brazil. \\ E-mail: jjailton@ufs.br, E-mail: rrsouza@ufs.br, \\ E-mail: inaura_rocha@yahoo.com.br,E-mail: carinassouza@gmail.com
}

(Received: July 23, 2007 ; Accepted January 18, 2008)

\begin{abstract}
A moving bed bioreactor containing cubes of polyether foam immersed in a synthetic wastewater (an aqueous mixture of meat extract, yeast extract, dextrose, meat peptone, ammonium chloride, potassium chloride, sodium chloride, sodium bicarbonate, potassium mono-hydrogen-phosphate and magnesium sulphate) was used to evaluate bacterial growth and biomass yield parameters based on Monod's equation. The wastewater was supplied in the bottom of the equipment flowing ascending in parallel with a diffused air current that provided the mixing of the reactor content. Suspended and attached biomass concentration was measured through gravimetric methods. Good agreement was found between experimental kinetic parameters values and those obtained by other researchers. The only significant difference was the high global biomass content about 2 times the values obtained in conventional processes, providing high performance with volumetric loading rates up to $5.5 \mathrm{~kg} \mathrm{COD} / \mathrm{m}^{3} / \mathrm{d}$.

Keywords: Fluidized bed; Immobilized biomass; Hybrid reactors.
\end{abstract}

\section{INTRODUCTION}

Biological wastewater treatment has been performed in many different ways since the beginning of the $20^{\text {th }}$ Century (Tyagi and Vembu, 1990). After the registration of the activated sludge patent in England in 1914, some modifications of this process were conceived, including the branch of moving bed biofilm reactors that operate with high biomass concentrations, providing high substrate removal rates (Heijnem et al., 1993).

In 1970's, in the USA, the ECOLOTROL ${ }^{\circledR}$ company patented another technique of wastewater treatment using biomass attached on inert carrier particles, giving arise to several moving bed biofilm reactors (Sutton e Mishra, 1994). Fan et al. (1989) have shown some systems involving the contact between solid, liquid and gas phases in a single equipment with special emphasis on air-lift, turbulent bed and fluidized bed reactors (Ouyang e Liaw, 1994; Lazarova e Manem, 1994; Tijhuis et al.,
1994). Recently, Sok'ol and Korpal (2006) used an inverse fluidized bed biofilm reactor (IFBBR) to treat a synthetic wastewater containing phenols. The most significant differences among these equipments are due to geometric design and operating strategy.

The particles of inert carriers have a capital role in this set of processes. According to Tavares et al. (1995), the microorganisms produce a kind of natural polymer responsible for their adhesion on the inert carrier surface developing the biofilm. Table 1 lists typical inert carriers reported by other authors.

The study consisted of biodegradation kinetics, suspended and attached biomass contents and organic matter removal rate - very important issues for reactor design. Most of the mathematical models presented in the literature are based on Monod's equation (Tchobanoglous et al., 2003), involving an endogenous decay term, as follows:

$\mathrm{r}_{\mathrm{g}}^{\prime}=\frac{\mu_{\mathrm{m}} \mathrm{X} \mathrm{S}}{\mathrm{K}_{\mathrm{s}}+\mathrm{S}}-\mathrm{k}_{\mathrm{d}} \mathrm{X}$ 
Table 1: Some inert carriers reported in the literature

\begin{tabular}{|l|c|c|c|l|}
\hline Inert Carrier & Diameter $\mathbf{( m m})$ & Density & $\mathbf{( \% ~ v / v ) ~}$ & Reference \\
\hline Sand & 0.20 & 2.65 & 10 & Heijnem et al. (1993); Dirkzwager et al. (1993) \\
Basalt & 0.26 & 3.00 & 5 & Heijnem et al. (1993); Tijhuis et al. (1994) \\
Granulated activated carbon & $0.40-0.59$ & 1.50 & NA & Coelhoso et al. (1992); Ouyang and Liaw (1994) \\
Hollow polyethylene & 10 & 0.95 & 5 & Rusten et al. (1994); Sok'ol and Korpal (2006) \\
cylinders & 2.7 & 1.18 & NA & Lazarova and Manen (1994) \\
Particles of polymers &
\end{tabular}

$\mathrm{NA}$ - no data available.

Laspidou (2003) presents a more complete kinetic model, taking in account seven chemical (carbonaceous, nitrogenous and phosphorous) species involved in the biodegradation reaction, but it requires further experiments that are beyond the scope of this work.

Literature data about the use of polyether foam as inert carriers for wastewater treatment are rare. Tharp and Frymier (1986); Tyagi and Vembu (1990); Gilligan and Morper (1999) report some results using polyurethane foam pads as support for biomass fixation related to the patented processes CAPTOR and LINPOR, that exhibit some operational differences in relation to the reactor used in this study, but are useful to make a comparison of their performance.

\section{MATERIAL AND METHODS}

The study was developed using a 3.8 liter moving bed biofilm reactor whose characteristics are listed below. The wastewater was synthesized by mixing meat extract, yeast extract, dextrose, meat peptone, ammonium chloride, potassium chloride, sodium chloride, potassium chloride, sodium bicarbonate, potassium mono-hydrogen-phosphate and magnesium sulphate, adapted from Hirata (2000). The ratio $\mathrm{C}: \mathrm{N}: \mathrm{P}$ was set around 100:5:1, following Eckenfelder's biodegradation criteria (Eckenfelder, 1992).

The determination of kinetic parameters and suspended biomass content was based on soluble and total COD measurements according to Tchobanoglous et al. (2003). A liquid sample containing suspended biomass was collected from the top of the reactor and its COD was measured in duplicate in two different ways: in the whole sample
- whose COD value quantified the soluble substrate plus the suspended biomass content, and in a filtered sample aliquot to evaluate the COD due to the soluble substrate.

The attached biomass was measured gravimetrically through the weight difference between bare and covered samples of the carrier, following the standard method applied to the determination of total suspended solids (Clesceri et al., 1998).

Reactor Characteristics:

Internal diameter. $0.60 \mathrm{~m}$ Cylindrical body diameter.............. $0.75 \mathrm{~m}$ Conical adapter height.............. $0.10 \mathrm{~m}$ Top diameter.................................. $0.12 \mathrm{~m}$ Cylindrical top height...................... $0.08 \mathrm{~m}$ Free board...................................... $0.10 \mathrm{~m}$

The inert carrier used was polyether foam cubes measuring $0.005 \mathrm{~m}$ on each side. This material has a density of 0.65 , hence is lighter than water, and a porosity of about $95 \%$.

A set of experimental situations was selected to cover a representative range of organic load and hydraulic retention time, as shown in Table 2.

The experiments were carried out using the maximum content of polyether foam $(0.13 \%$ by volume) and the air flow of $2 \mathrm{~L}$ per minute. The optimal content was obtained using hydrodynamic tests, according to Marques (2003), corresponding to the maximum concentration of solids in which a stable operation could be achieved without any bed clogging. This percentage of support represents only the volume fraction occupied by the solid framework of foam pads. If the void space is included, the support content increases to 2.0 percent.

Table 2: Experimental parameters and respective ranges of studied values

\begin{tabular}{|l|r|r|}
\hline Parameter & Dimension & Values \\
\hline Polyether foam fraction & $\% \mathrm{v} / \mathrm{v}$ & $0.13(2.70 \mathrm{~g})$ \\
Air flowrate & $\mathrm{L} / \mathrm{min}$ & 2.0 \\
Hydraulic retention time & $\mathrm{h}$ & $2 ; 3 ; 4 ; 5$ \\
COD level & $\mathrm{mg} / \mathrm{L}$ & $400 ; 500 ; 600 ; 1000$ \\
\hline
\end{tabular}




\section{RESULTS AND DISCUSSION}

The experimental results obtained from several runs are listed in Table 3.

The kinetic parameters of Monod's model were obtained through data regression, by taking into account endogenous decay as discussed before. The optimized values found are listed in Table 4.

\section{Biomass Attachment Capacity of Polyether Foam}

The assessment of biomass fixation in polyether foam cubes (that include the biomass occluded in macroporous media) was carried out through typical biodegradation tests by measuring gravimetrically the increase of fixed biomass content with varying operation time. The results are shown in Figure 1.

It is clear that biomass fixation in polyether foam is very fast in comparison with the colonization of carbon particles reported by Tyagi and Vembu (1990). This process takes several days to be completed because the fixation of biomass on particle surface depends on the generation of a polysaccharide by the microorganisms, according to Laspidou (2003). Probably, in the polyether matrix, the main mechanism involved was the entrapment of biomass flocks instead of the attachment of microorganisms on the surface. Although the biomass can be loose in the three-dimensional frame of the inert carrier, high reactor biomass contents are attained. After about 30 hours of continuous operation, the system becomes saturated.

Table 3: Experimental results under investigated operational conditions

\begin{tabular}{|c|c|c|c|c|c|c|}
\hline Run & Carrier & $\mathrm{Q}$ (mL/min) & $\mathrm{S}_{0}(\mathrm{mg} / \mathrm{L})$ & $\theta=\theta_{c}(d)$ & $\mathrm{S}(\mathrm{mg} / \mathrm{L})$ & $X(\mathrm{mg} / \mathrm{L})$ \\
\hline 1 & - & 25.2 & 534 & 0.106 & 116 & 138 \\
\hline 2 & - & 16.8 & 1003 & 0.158 & 100 & 452 \\
\hline 3 & - & 21.0 & 632 & 0.127 & 179 & 91 \\
\hline 4 & - & 21.0 & 569 & 0.127 & 340 & 76 \\
\hline 5 & - & 21.0 & 350 & 0.127 & 69 & 141 \\
\hline 6 & POL & 25.2 & 460 & 0.106 & 50 & 166 \\
\hline 7 & POL & 25.2 & 397 & 0.106 & 23 & 23 \\
\hline 8 & POL & 31.5 & 400 & 0.084 & 124 & 53 \\
\hline 9 & POL & 16.8 & 334 & 0.158 & 39 & 39 \\
\hline 10 & POL & 16.8 & 256 & 0.158 & 48 & 12 \\
\hline 11 & POL & 21.0 & 417 & 0.127 & 108 & 13 \\
\hline 12 & POL & 16.8 & 967 & 0.158 & 98 & 94 \\
\hline 13 & POL & 21.0 & 484 & 0.127 & 150 & 50 \\
\hline 14 & POL & 12.6 & 589 & 0.211 & 210 & 56 \\
\hline
\end{tabular}

Note: The polyether foam content (POL) was fixed equal to $0.13 \% \mathrm{v} / \mathrm{v}$ and the hydraulic retention time $(\theta)$ was established equal to the cells age $\left(\theta_{\mathrm{c}}\right)$ because the reactor was operated without recycle.

Table 4: Optimized values of kinetic and biomass growth parameters

\begin{tabular}{|c|r|r|}
\hline Parameter & Unit & \multicolumn{1}{|c|}{ Value } \\
\hline$\mu_{\mathrm{m}}$ & $\mathrm{d}^{-1}$ & 3 \\
$\mathrm{~K}_{\mathrm{s}}$ & $\mathrm{mg} \mathrm{COD} / \mathrm{L}$ & 74 \\
$\mathrm{k}_{\mathrm{d}}$ & $\mathrm{d}^{-1}$ & 0.07 \\
$\mathrm{Y}$ & $\mathrm{mg} \mathrm{TSS} / \mathrm{mg} \mathrm{COD}^{-1}$ & 0.44 \\
$\mathrm{k}$ & $\mathrm{d}^{-1}$ & 4.1 \\
\hline
\end{tabular}

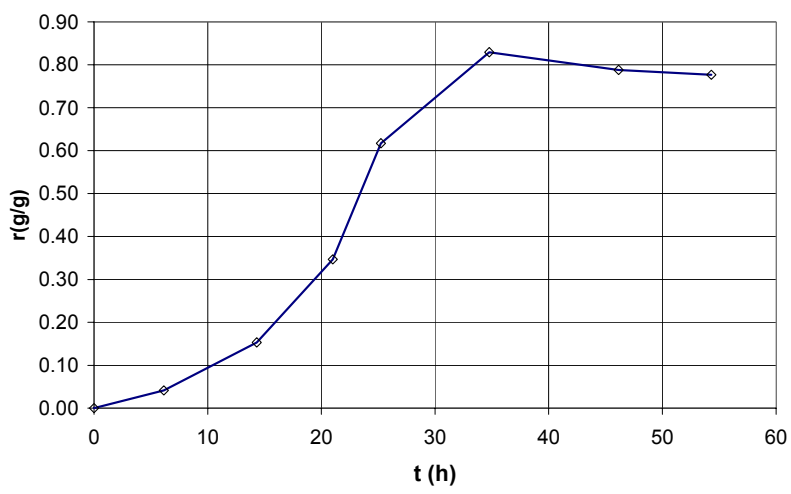

Figure 1: Biomass to carrier mass ratio versus time; $Q=25.2 \mathrm{~mL} / \mathrm{min} ; \mathrm{COD}=397 \mathrm{mg} / \mathrm{L} ; \mathrm{Q}_{\mathrm{ar}}=2 \mathrm{~L} / \mathrm{min}$ 


\section{Effect of Organic Load on The Substrate Removal}

The activated sludge reactors show a good performance at relatively low organic load (Tchobanoglous et al., 2003). Beyond a certain limit their efficiencies tend to decay as shown in Figure 2.

The substrate utilization rate increases with the organic load until a given limit. The optimal values achieved were at $3.3 \mathrm{~kg} \mathrm{COD} / \mathrm{m}^{3} / \mathrm{d}$, corresponding to a substrate removal rate of $62 \mathrm{~kg} \mathrm{COD} / \mathrm{kg}$ biomass $/ \mathrm{d}$. Thus, the moving bed bioreactor used provided a substrate removal capacity about 2 times the values obtained in a conventional activated sludge reactor using real sanitary effluent (Tchobanoglous et al., 2003), just as predicted by Heijnem et al. (1993). Of course, it must be taken into account that the wastewater used in all the experiments was synthesized and probably more easily degradable than real sanitary wastewater.

Figure 3 shows another comparison involving the organic load (OL) and the volumetric load rate (VLR). There is a linear relation between these two parameters, just like that reported by Jianlong et al. (2000).

These results can be compared with previously obtained data using similar polymeric materials as biomass support, as shown in Table 5.

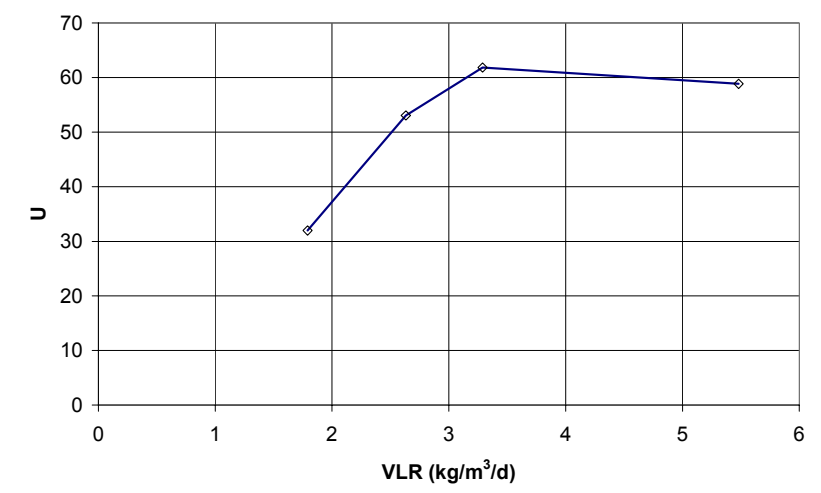

Figure 2: Correlation between substrate utilization rate and volumetric load rate

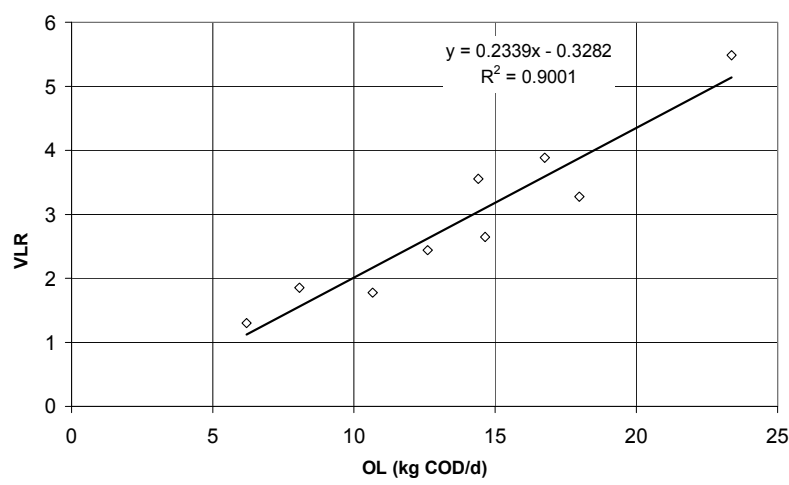

Figure 3: Correlation between organic load and volumetric substrate removal rate

Table 5: Comparison between this work and literature data

\begin{tabular}{|c|c|c|c|c|}
\hline Process & Support Type & $\begin{array}{c}\text { Support Content } \\
(\%)\end{array}$ & $\begin{array}{c}\text { Biomass Content } \\
(\mathrm{mg} / \mathrm{L})\end{array}$ & Reference \\
\hline CAPTOR $^{\circledR}$ & Polyurethane foam pads & $15-75$ & $7,000-9,000$ & $\begin{array}{l}\text { Tyagi and Vembu (1990); } \\
\text { Tharper and Frymier (1986) }\end{array}$ \\
\hline LINPOR $^{\circledR}$ & Polyurethane foam pads & $10-40$ & $5,000-8,000$ & $\begin{array}{l}\text { Tyagi and Vembu (1990); } \\
\text { Gilligan and Morper (1999) }\end{array}$ \\
\hline This work & Polyether foam pads & 2 & 650 & - \\
\hline This work & Polyether foam pads & $10-40$ & $3,250-13,000^{(*)}$ & - \\
\hline
\end{tabular}

${ }^{(*)}$ Extrapolation based on LINPOR process support content range. 
Although the support and biomass contents found in this study are out of the range obtained by the other researchers, if a linear extrapolation in biomass content, based on LINPOR ${ }^{\circledR}$ process support content, is assumed, the estimated values of biomass concentration would vary from 3,250 to 13,000 $\mathrm{mg} / \mathrm{L}$. For instance, operational limitations such as clogging problems, common in reactors with reduced internal diameter, were not observed.

\section{CONCLUSIONS}

The kinetic parameter values obtained are not significantly different from those reported in the literature. The organic load and the substrate utilization rates achieved were so high due to the high biomass to carrier ratios, whose maximum value was about $0.8 \mathrm{~kg}$ biomass $/ \mathrm{kg}$ inert carrier.

This result confirms that moving bed biofilm reactors tolerate around 2 times the volumetric organic loads experienced by the other modalities of activated sludge reactor processes.

The main advantage of this kind of process is the possibility of building a wastewater treatment plant in small areas. Another important issue is that a conventional plant can have its capacity increased by using suspended inert carriers like polyether or polyurethane foam pads.

\section{ACKNOWLEDGEMENTS}

The authors are thankful to Fundação de Amparo à Pesquisa do Estado de Sergipe (FAPSE/FUNTEC), to CNPq/MCT for the sponsorship of the study, to the Instituto de Tecnologia e Pesquisa ITP (Aracaju - SE - Brazil), where the study was developed.

\section{NOMENCLATURE}

$\begin{array}{llr}\text { COD } & \begin{array}{l}\text { chemical oxygen demand } \\ \text { endogenous decay }\end{array} & \mathrm{mg} / \mathrm{L} \\ \mathrm{k}_{\mathrm{d}} & \begin{array}{l}\mathrm{h}^{-1} \\ \text { coefficient }\end{array} & \mathrm{mg} / \mathrm{L} \\ \mathrm{K}_{\mathrm{s}} & \text { half-velocity constant } & \mathrm{kgCOD} / \mathrm{d} \\ \mathrm{OL} & \begin{array}{l}\text { organic load } \\ \mathrm{mL} / \mathrm{min}\end{array} \\ \mathrm{Q} & \begin{array}{l}\text { feed flowrate } \\ \mathrm{Q}_{\mathrm{ar}}\end{array} & \text { air flowrate } \\ \mathrm{R} & \text { biomass to carrier mass ratio } & \mathrm{L} / \mathrm{min} \\ \mathrm{r}_{\mathrm{g}} & \text { net rate of bacterial growth } & \text { mass/volume/ } \\ & & \text { time } \\ \mathrm{S} & \text { concentration of growth- } & \mathrm{mg} / \mathrm{L}\end{array}$

reactor content

$\mathrm{S}_{\mathrm{O}} \quad$ concentration of growth- $\mathrm{mg} / \mathrm{L}$ limiting substrate in the feed stream

U volumetric substrate $\quad \mathrm{kg} \mathrm{COD} / \mathrm{kg}$ removal rate

VLR volumetric load rate

$\mathrm{X}$ biomass concentration

$\mu \quad$ specific growth rate

$\mu_{\mathrm{m}} \quad$ maximum specific growth rate

$\theta \quad h y d r a u l i c$ retention time $h$

$\theta_{c}$ mean cell retention time or $h$. sludge age

\section{REFERENCES}

Clesceri, L. S., Greenberg, A. E. and Eaton, A. D., Standard Methods for the Examination of Water and Wastewater. American Public Health Association, American Water Works Association \& Water Pollution Control Federation, 20 $0^{\text {th }}$ edition, Washington, D.C. (1998).

Dirkzwager, A. H., Jong, J. and Stamperius, P. C., The Research Programme "RWZI": State of Affairs and a Look into the Future. Water Science and Technology, 27 (5-6): 35-47 (1993).

Eckenfelder, W. W. and Grau, P., Activated Sludge Process Design and Control: Theory and Practice, vol. 1, Technomic Publishing, Lancaster (1992).

Coelhoso, I., Boaventura R. and Rodrigues, A., Biofilm Reactors: an Experimental and Modelling Study of Wastewater Denitrification in FluidizedBed Reactors of Activated Carbon Particles. Biotechnology and Bioengineering, 40: 625-633 (1992).

Fan, L. S., Gas-Liquid-Solid Fluidization Engineering, vol. 2, Butterworth Publishers, Boston (1989).

Gilligan, T. P. and Morper, M. A Unique Process for Upgrading Conventional Activated Sludge Systems for Nitrogen Removal, presented at NE WEA, October (1999).

Heijnem, J. J., van Loosdrecht, M. C. M., Mulder, R. and Weltverede et al. Development and Scale-up of an Aerobic Air-Lift Suspension Reactor. Water Science and Technology, 27 (5-6): 253-261 (1993).

Hirata, T.; Takemoto, T.; Ogawa, K.; Auresenia, J. and Tsuneda, S., Evaluation of Kinetic Parameters of Biochemical Reaction in ThreePhase Fluidized Bed Biofilm Reactor for Wastewater Treatment. Biochem. Eng. J., 5 (2): 165-171 (2000). 
Jianlong, W., Hanchang, S. and Yi, Q, Wastewater Treatment in a Hybrid Biological Reactor (HBR): Effect of Organic Loading Rates, Process Biochem. 36: 297-303 (2000).

Laspidou, C. S., Modeling Biofilms Including Active Biomass, Inert Biomass and Extracellular Polymeric Substances. Ph.D. Thesis, Civil and Environmental Engineering/Northwestern University - Evanston - Illinois - EUA (2003).

Lazarova, V. and Manem, J., Advances in Biofilm Aerobic Reactors Ensuring Effective Biofilm Activity Control, Water Science and Technology, 29 (10-11): 319-327 (1994).

Marques, J. J., Desenvolvimento de um Reator de Leito Fluidizado Híbrido para o Tratamento de Efluentes Industriais. Ph.D. Thesis, DESQ/FEQ/ UNICAMP, Campinas-SP-Brasil (2003).

Tchobanoglous, G., Burton, F. L. and Stensel, H. D., Wastewater Engineering: Treatment and Reuse, $4^{\text {th }}$ edition, Mc Graw-Hill, New York (2003).

Ouyang, C. F. and Liaw, C. M., The Optimum Medium of the Suspended Bio-Medium Aeration Contactor Process. Water Science and Technology, 29 (10-11): 183-188 (1994).

Rusten, B., Siljudalen, J. G. and Nordeit, B., Upgrading to Nitrogen Removal with the KMT
Moving Bed Biofilm Process. Water Science and Technology, 29 (12): 185-195 (1994).

Sutton, P. M. and Mishra, P. N. Activated Carbon Based Biological Fluidized Beds, Water Science and Technology, 29 (10-11): 310-317 (1994).

Sok'ol, W. and Korpal, W. Aerobic Treatment of Wastewaters in the Inverse Fluidised Bed Biofilm Reactor. Chemical Engineering Journal, 118: 199-205 (2006).

Tharp, C. E. and Frymier, M., High Intensity Biological Systems Using the Captivated Sludge Process, presented at $59^{\text {th }}$ Water Pollution Control Federation Conference, Los Angeles, October 5 to 9 (1986).

Tyagi, R. D. and Vembu, K., Wastewater Treatment by Immobilized Cells, CRC Press, Boca Raton (1990).

Tavares, C. R. G., Sant'anna Jr., G. L. and Capdeville, B., The Effect of Air Superficial Velocity on Biofilm Accumulation in a ThreePhase Fluidized-Bed Reactor. Water Resources, 29 (10): 2293-2298 (1995).

Tijhuis, L., van Loosdrecht, M. C. M. and Heijnem, J. J., Formation and Growth of Heterotrophic Aerobic Biofilms on Small Suspended Particles in Airlift Reactors. Biotechnology and Bioengineering, 44: 595-608 (1994). 